\title{
Detection of Cardiovascular Disease in Elite Athletes Using Cardiac Magnetic Resonance Imaging
}

\author{
Kardiale Magnetresonanztomografie zur \\ Risikostratifizierung in Leistungssportlern
}

\author{
Authors \\ S. Mangold ${ }^{1}$, U. Kramer' ${ }^{1}$, E. Franzen², G. Erz ${ }^{2}$, C. Bretschneider ${ }^{1}$, A. Seeger ${ }^{3}$, C. D. Claussen ${ }^{1}$, A. M. Niess², \\ C. Burgstahler ${ }^{2}$ \\ Affiliations \\ Department of Diagnostic and Interventional Radiology, University of Tuebingen \\ Department of Internal Medicine V, Sports Medicine, University of Tuebingen \\ Department of Diagnostic and Interventional Neuroradiology, University of Tuebingen, Tuebingen
}

\author{
Key words \\ - heart \\ - cardiac \\ - MR functional imaging \\ - MR angiography \\ - ischemia/infarction \\ - normal variants
}

eingereicht 2.4 .2013

akzeptiert 14.6.2013

Bibliography

DOI http://dx.doi.org/

$10.1055 / \mathrm{s}-0033-1350130$

Published online: 29.7.2013

Fortschr Röntgenstr 2013; 185:

1167-1174 @ Georg Thieme

Verlag KG Stuttgart · New York .

ISSN 1438-9029

\author{
Correspondence \\ Prof. Dr. U. Kramer \\ Department of Diagnostic and \\ Interventional Radiology, \\ University of Tuebingen \\ Hoppe-Seyler-Str. 3 \\ 72076 Tuebingen \\ Germany \\ Tel.: ++49/07 07/ 12986677 \\ Fax: $++49 / 0707 / 1294638$ \\ Ulrich.Kramer@med. \\ uni-tuebingen.de
}

\section{Zusammenfassung \\ $\nabla$}

Ziel: In der Genese von plötzlichem Herztod bei Leistungssportlern spielen neben der hypertrophen und dilatativen Kardiomyopathie [HCM/ DCM] auch die Myokarditis, Koronaranomalien und ischämische Herzerkrankungen eine wichtige Rolle. Zur Abklärung dieser potentiellen Risikofaktoren erfolgte die Durchführung einer kardialen Magnetresonanztomografie [MRT]. Material und Methoden: 73 männliche [M] und 22 weibliche [F] Athleten (Durchschnittsalter 35,2 \pm 11,4 Jahre) wurden einer kardialen MRT zugeführt. EKG-getriggerte cine SSFP Sequenzen wurden verwendet um Wandbewegungsstörungen und Myokardhypertrophien zu diagnostizieren und um quantitative Auswertungen durchzuführen (linksund rechtsventrikuläres [LV, RV] enddiastolisches und endsystolisches Volumen [EDV, ESV], Schlagvolumen [SV], Ejektionsfraktion [EF] und die Myokardmasse [MM]). Zusätzlich wurden die Vorhofgrößen planimetrisch erfasst und Kontrastmittel injiziert, um fibrotische Veränderungen des Myokards nachzuweisen. Die Darstellung der Koronararterien erfolgte mittels einer Flash-3-D-MR-Angiografie.

Ergebnisse: Die quantitativen Analysen zeigten eine exzentrische LV-Hypertrophie (remodeling index [MM/LV-EDV]: männlich 0,75 , weiblich 0,665), erhöhte RV-Volumina (RV-EDV: M 122,6 \pm $19,0 \mathrm{ml} / \mathrm{m}^{2}$, F 99,9 $\pm 7,2 \mathrm{ml} / \mathrm{m}^{2}$ ) sowie erhöhte SV (LV-SV: M $64,7 \pm 10,0 \mathrm{ml} / \mathrm{m}^{2}$, F $56,5 \pm 5,7 \mathrm{ml} / \mathrm{m}^{2}$; RV-SV: M $66,7 \pm 10,4 \mathrm{ml} / \mathrm{m}^{2}$, F $54,2 \pm 7,1 \mathrm{ml} / \mathrm{m}^{2}$ ). Pathologische Befunde fanden sich in 6 Athleten $(6,3 \%)$, darunter eine benigne Variante einer Koronaranomalie sowie fibrotische Myokardveränderungen in 2 Fällen. Wandbewegungsstörungen oder postischämische Veränderungen fanden sich hingegen nicht.

Schlussfolgerung: Die durchgeführte kardiale MRT in Leistungssportlern zeigte pathologische Befunde in über $5 \%$ der Athleten, wobei die prog-

\section{Abstract \\ $\nabla$}

Purpose: Sudden cardiac death [SCD] in competitive athletes is caused by a diverse set of cardiovascular diseases such as hypertrophic and dilated cardiomyopathy [HCM/DCM], myocarditis, coronary anomalies or even coronary artery disease. In order to identify potential risk factors responsible for SCD, elite athletes underwent cardiac magnetic resonance [CMR] imaging.

Materials and Methods: 73 male $[\mathrm{M}]$ and 22 female [F] athletes (mean age $35.2 \pm 11.4$ years) underwent CMR imaging. ECG-gated breath-hold cine SSFP sequences were used for the evaluation of wall motion abnormalities and myocardial hypertrophy as well as for quantitative analysis (left and right ventricular $[\mathrm{LV}, \mathrm{RV}]$ end-diastolic and end-systolic volume [EDV, ESV], stroke volume [SV], ejection fraction [EF] and myocardial mass [MM]). Furthermore, left and right atrial sizes were assessed by planimetry and delayed enhancement imaging was performed 10 minutes after the application of contrast agent. Coronary arteries were depicted using free-breathing Flash3D MR angiography.

Results: The quantitative analyses showed eccentric hypertrophy of the left ventricle (remodeling index [MM/LV-EDV]: M 0.75, F 0.665), enlargement of the RV volumes (RV-EDV: M 122.6 $\pm 19.0 \mathrm{ml} / \mathrm{m}^{2}, \mathrm{~F} 99.9 \pm 7.2 \mathrm{ml} / \mathrm{m}^{2}$ ) and an increased SV (LV-SV: M $64.7 \pm 10.0 \mathrm{ml} / \mathrm{m}^{2}$, F $56.5 \pm 5.7 \mathrm{ml} /$ $\mathrm{m}^{2}$; RV-SV; M $66.7 \pm 10.4 \mathrm{ml} / \mathrm{m}^{2}$, F $54.2 \pm 7.1 \mathrm{ml} /$ $\mathrm{m}^{2}$ ). Abnormal findings were detected in 6 athletes $(6.3 \%)$ including one benign variant of coronary anomaly and abnormal late gadolinium enhancement in 2 cases. None of the athletes showed wall motion abnormalities or signs of myocardial ischemia.

Conclusion: CMR imaging of endurance athletes revealed abnormal findings in more than $5 \%$ of the athletes. However, the prognostic significance remains unclear. Thus, cardiac MRI cannot 
nostische Relevanz solcher Befunde zunächst nicht abschließend zu beurteilen ist. Daher ist die routinemäßige Durchführung einer kardialen MRT in Leistungssportlern primär nicht zu empfehlen.

Kernaussagen:

- Die MRT liefert einen wichtigen Beitrag zur Diagnostik von kardiovaskulären Erkrankungen in Athleten.

- Die Differenzierung von physiologischen Anpassungsreaktionen und einer DCM/HCM stellt eine große Herausforderung dar.

- Eine routinemäßige Durchführung einer kardialen MRT in Leistungssportlern kann nicht empfohlen werden. be recommended as a routine examination in the care of athletes.

Key points:

- CMR imaging helps clinicians to detect cardiovascular diseases in elite athletes.

- Differentiation between physiological adaptations and DCM/ HCM can be a challenging task.

- Routine cardiac MRI examinations of endurance athletes cannot be recommended.

Citation Format:

- Mangold S, Kramer U, FranzenE et al. Detection of Cardiovascular Disease in Elite AthletesUsing Cardiac Magnetic Resonance Imaging. Fortschr Röntgenstr 2013; 185: 1167-1174

\section{Introduction}

$\nabla$

As competitive athletes symbolize vitality and health, they have always been granted a status of special appreciation and prestige. This may explain the sense of tragedy that comes with sudden cardiac death (SCD) in athletes, caused by a diverse set of cardiovascular diseases such as hypertrophic and dilated cardiomyopathy (HCM/DCM), myocarditis, arrhythmogenic right ventricular disease (ARVD), coronary anomalies or even coronary artery disease (CAD) [1, 2]. An overall incidence of 2.1/100,000/year [2] has fuelled interest in pre-participation screening and the identification of the risk factors commonly responsible for SCD in elite athletes [3-5]. Of note, morphological and functional adaptations of the cardiovascular system related to endurance training [6-10] must be distinguished from pathological findings of the myocardium. Congenital or acquired anomalies should be excluded in order to minimize the risk for cardiac events during physical activity. Previous approaches to pre-participation testing included personal and family history as well as physical examination $[3,4,11-13]$. Due to a high percentage of abnormal electrocardiographic (ECG) findings in HCM [14] and ARVD [5, 11, 12], an additional 12-lead ECG is recommended [15] since it has the potential to increase the sensitivity of the screening progress [5, 15 -17]. However, these tests and even performing an additional echocardiography may fail to detect risk factors especially with regard to coronary anomalies and subtle ischemic and non-ischemic myocardial fibrosis. In this context, CMR imaging has turned out to be the method of choice using delayed enhancement and high-resolution $3 \mathrm{D}$ imaging techniques [18-21]. Furthermore, CMR imaging allows the assessment of ventricular chamber volumes and functional parameters with good interand intraobserver reliability [21,22].

The purpose of this study was to quantify the prevalence of potential risk factors and determine ventricular functional parameters using CMR in elite athletes with unremarkable pre-participation screening.

\section{Methods \\ $\nabla$}

\section{Study population}

The study protocol was approved by the institutional ethics committee and all participants gave written informed consent prior to the study.

We prospectively enrolled 100 healthy athletes (mean age $35.2 \pm$ 11.4 years, range from 18 to 62 years; 77 males, mean age $37.4 \pm$
11.4 years, range from 19 to 62 years; 23 females, mean age 28.4 \pm 8.5 years, range from 18 to 50 years). The athletes were highly trained long-distance runners $(n=39)$, cyclists $(n=8)$, triathletes $(n=34)$, handball players $(n=13)$ and one speed skater with a training history of at least two years and a weekly training workload of $13.1 \pm 4.2$ hours (males: $13.1 \pm 4.5$ hours/week, range from 5 to 30 hours/week; females: $12.8 \pm 3$ hours/week, range from 7 to 20 hours/week). The physical characteristics of the athletes are given in detail in $\bullet$ Table 1.

In standard pre-participation screening which was performed prior to the CMR examination, none of the participants showed any pathologies prohibiting their sports activities. The BNP values were within normal ranges $(<100 \mathrm{ng} / \mathrm{l})$ in all athletes and none of the participants reported previous cardiovascular disease. Furthermore, all athletes denied taking prohibited substances.

\section{Cardiac magnetic resonance imaging protocol}

All examinations ( $n=95$ ) were performed on a 1.5 Tesla MR system (Magnetom Avanto, Siemens Medical Solutions, Forchheim, Germany) using surface coils for signal reception. In 5 cases no CMR imaging data sets could be generated because of the withdrawal of informed consent. For the evaluation of wall motion abnormalities and myocardial hypertrophy, $2 \mathrm{D}$ cine steady-state free precession (SSFP) sequences were acquired in a 4-chamber view, left ventricular long axis view (ECG-retrogating, repetition time (TR) 39.75, echo time (TE) $1.12 \mathrm{~ms}$, angle of excitation (FA) $70^{\circ}$, field of view (FOV) adapted to each athlete, pixel spacing $1.8 \times 1.8$, matrix $156 \times 192$, slice thickness $(\mathrm{SL}) 6 \mathrm{~mm}$, bandwidth (BW) $930 \mathrm{~Hz} /$ pixel) as well as in short axis angulation (ECG-retrogating, TR $58.96 \mathrm{~ms}$, TE $1.13 \mathrm{~ms}$, FA $70^{\circ}$, pixel spacing $2.4 \times 1.8$, matrix $113 \times 192$, SL 5 mm, BW $930 \mathrm{~Hz} /$ pixel).

For coronary MR angiography (MRA), an ECG-gated 3 D GRE/SSFP sequence was combined with respiratory navigator gating and

Table 1 Physical characteristics.

Tab. 1 Körperliche Eigenschaften.

\begin{tabular}{|llll|}
\hline & total & male & female \\
\hline age $[$ years] & $35.2 \pm 11.4$ & $37.4 \pm 11.4$ & $28.4 \pm 8.5$ \\
\hline height $[\mathrm{m}]$ & $1.78 \pm 7.6$ & $1.81 \pm 6.1$ & $1.7 \pm 6.2$ \\
\hline weight $[\mathrm{kg}]$ & $71 \pm 9.7$ & $72.9 \pm 8.4$ & $65.2 \pm 11.4$ \\
\hline BSA [kg/m²] & $1.87 \pm 0.16$ & $1.91 \pm 0.13$ & $1.7 \pm 0.2$ \\
\hline heart rate $[\mathrm{bpm}]$ & $55 \pm 6.9$ & $53 \pm 6.7$ & $58 \pm 7.3$ \\
\hline VO2 max.[ml/min] & $55.5 \pm 7.9$ & $57.3 \pm 6.9$ & $50.1 \pm 8.7$ \\
\hline training hours/week & $13.1 \pm 4.2$ & $13.1 \pm 4.5$ & $12.8 \pm 3$ \\
\hline
\end{tabular}


tracking. The respiratory navigator was localized at the lung-liver interface of the right hemidiaphragm with a $2 \mathrm{~mm}$ gating window. The acquisition window and TR were adapted to the duration of the end-diastolic period of rest and an individual trigger delay was determined in order to minimize myocardial motion artifacts during the acquisition interval. The following settings were used: spatial resolution (voxel size) $1.0 \times 1.0 \times 1.1 \mathrm{~mm}$, TE $1.75 \mathrm{~ms}$, FA $90^{\circ}$, matrix $216 \times 320$, BW $601 \mathrm{~Hz} /$ pixel.

Furthermore, delayed enhancement imaging was performed 10 minutes after administration of $0.15 \mathrm{mmol} / \mathrm{kg}$ body weight Gadobutrol (Gadovist, Bayer Healthcare, Leverkusen, Germany) at a flow rate of $2.0 \mathrm{ml} / \mathrm{s}$ using an inversion recovery [IR] turbo FLASH $2 \mathrm{D}$ sequence (TR $700 \mathrm{~ms}$. TE $4.91 \mathrm{~ms}$, FA $30^{\circ}$, matrix $154 \times 256$, pixel spacing $1.5 \times 1.12 \mathrm{~mm}$, SL $8 \mathrm{~mm}$, BW $140 \mathrm{~Hz} /$ Pixel). Optimal inversion time (TI) was determined using a TI scout sequence (TR $23.49 \mathrm{~ms}$, TE $1.12 \mathrm{~ms}$, FA $60^{\circ}$, pixel spacing $3.5 \times 1.8 \mathrm{~mm}$, matrix $78 \times 192$, SL $8 \mathrm{~mm}$, BW $965 \mathrm{~Hz} /$ Pixel) to minimize the signal intensity of normal myocardium.

\section{Imaging analyses}

Two experienced readers independently reviewed the image loops of each subject in a random fashion. Readers were blinded for subject details including age and training hours/week.

Quantitative analysis was performed off-line using dedicated software (Leonardo VD30B, Siemens Medical Solutions). The left ventricular (LV) and right ventricular (RV) wall mass and volumes were measured by tracing the endocardial and epicardial borders on the short-axis views. At the base of the LV, the aorta was included in the LV volume below the aortic valve. Blood volumes above the aortic valve, as well as volumes surrounded by a thin myocardial wall on the mitral valve plane (left atrial blood volume), were excluded from the LV volume and the basal slice was selected for the left ventricle when at least $50 \%$ of the blood volume was surrounded by myocardium in both end-diastole and end-systole. By inspection of the cine loops, end-systole was defined as the frame with the smallest ventricular cavity. Papillary muscles and trabeculae were included in the ventricular volumes (and excluded from the wall mass) for efficiency and reproducibility. Epicardial fat and the pericardium were excluded from the RV and LV mass [17]. End-diastolic volumes (EDV) and end-systolic volumes (ESV) of the LV and RV were calculated according to a modified Simpson's rule in short axis views [17 - 19] and were used to determine stroke volume (SV) and ejection fraction (EF). The LV mass was determined by summation of EDVs within the epicardial and endocardial borders of the short-axis slices and by multiplying the myocardial tissue volume by its specific density of $1.05 \mathrm{~g} / \mathrm{cm} 3$. Atrial sizes were assessed by planimetry of the maximum right atrial (RA) and left atrial (LA) areas in a standard 4-chamber view just before the opening of the mitral valve. Pulmonary veins were excluded from the LA area [18]. Additionally, all parameters were indexed to the body surface area (BSA) for comparative analysis in order to minimize differences of cardiac parameters related to height and weight. The LV remodeling index (MM/LV-EDV) was calculated to determine the pattern of ventricular remodeling.

Delayed enhancement images, the MR coronary angiography and the Cine SSFP images were evaluated visually regarding wall motion abnormalities, coronary anomalies and ischemic or non-ischemic patterns of delayed myocardial enhancement. In the event of a deviation between both readers, the images were reevaluated by both radiologists in consensus.

\section{Statistics}

The data were statistically analyzed using SPSS software, version 11.5 (SPSS, Inc, Chicago, USA). Continuous data are presented as mean \pm standard deviation. Normality was tested using the Kolmogorov-Smirnov test. The inter-reader agreement regarding chamber volumes, functional parameters and MM were evaluated using the Cohen's Kappa test. Pearson correlation coefficients were calculated for selected variables. A p-value of less than 0.05 was considered statistically significant.

\section{Results \\ $\nabla$}

For cine SSFP and delayed enhancement images, diagnostic image quality was obtained in all of the 95 MRI examinations. The mean total imaging time was 50:42 min \pm 10 :12 min (range from 34 to $74 \mathrm{~min}$ ) and the acquisition time of the MR coronary angiography was $14: 33 \mathrm{~min} \pm 5: 25 \mathrm{~min}$ (range from 6:34 to 44:42 min). The results of the evaluation of the chamber volumes, atrial sizes and functional parameters are given in detail in $\bullet$ Table 2 and

Table 2 Results of the evaluation of the ventricular volumes and functional parameters. A p-value of $<0.05$ was regarded as statistically significant. $\mathrm{K}$-value in parentheses. [LV] left ventricular [RV] right ventricular [EDV] end-diastolic volume [ESV] end-systolic volume [SV] stroke volume [EF] ejection fraction [MM] myocardial mass [LA] left atrium [RA] right atrium.

Tab. 2 Ergebnisse der quantitativen Auswertung von Ventrikelvolumina und Funktionsparametern. Ein p-Wert von <0,05 wurde als statistisch signifikant erachtet. к-Werte in Klammern. [LV] linker Ventrikel [RV] rechter Ventrikel [EDV] enddiastolisches Volumen [ESV] endsystolisches Volumen [SV] Schlagvolumen [EF] Ejektionsfraktion [MM] Myokardmasse [LA] linker Vorhof [RA] rechter Vorhof.

\begin{tabular}{|c|c|c|c|c|}
\hline & total & male & female & p-values \\
\hline LV-EDV $\left[\mathrm{ml} / \mathrm{m}^{2}\right]$ & $103.3 \pm 13.1(0.80)$ & $106.5 \pm 12.9$ & $92.7 \pm 6.4$ & $<0.001$ \\
\hline LV-ESV $\left[\mathrm{ml} / \mathrm{m}^{2}\right]$ & $40.4 \pm 8.2(0.78)$ & $41.8 \pm 8.5$ & $36.3 \pm 5.2$ & 0.007 \\
\hline LV-SV $\left[\mathrm{ml} / \mathrm{m}^{2}\right]$ & $62.9 \pm 9.7(0.81)$ & $64.7 \pm 10.0$ & $56.4 \pm 5.7$ & 0.001 \\
\hline LV-EF [\%] & $60.8 \pm 5.7(0.75)$ & $60.8 \pm 6.0$ & $60.9 \pm 4.8$ & 0.916 \\
\hline $\mathrm{RV}-\mathrm{EDV}\left[\mathrm{ml} / \mathrm{m}^{2}\right]$ & $118.4 \pm 19.7(0.67)$ & $126.6 \pm 19.0$ & $99.9 \pm 7.2$ & $<0.001$ \\
\hline $\mathrm{RV}-\mathrm{ESV}\left[\mathrm{ml} / \mathrm{m}^{2}\right]$ & $56.1 \pm 14.2(0,65)$ & $59.9 \pm 14.5$ & $45.7 \pm 7.3$ & $<0.001$ \\
\hline $\mathrm{RV}-\mathrm{SV}\left[\mathrm{ml} / \mathrm{m}^{2}\right]$ & $62.3 \pm 10.4$ & $66.7 \pm 10.4$ & $54.2 \pm 7.1$ & $<0.001$ \\
\hline RV-EF[\%] & $56.2 \pm 5.4(0.60)$ & $52.6 \pm 6.4$ & $54.7 \pm 5.6$ & 0.191 \\
\hline $\mathrm{MM}\left[\mathrm{g} / \mathrm{m}^{2}\right]$ & $74.8 \pm 11.9(0.78)$ & $78.9 \pm 10.2$ & $61.4 \pm 5.4$ & $<0.001$ \\
\hline remodeling index & 0.726 & 0.750 & 0.665 & 0.0001 \\
\hline $\mathrm{LA}\left[\mathrm{cm}^{2}\right]$ & $23.7 \pm 4.7$ & $24.8 \pm 4.6$ & $20.3 \pm 3.6$ & 0.0001 \\
\hline $\mathrm{RA}\left[\mathrm{cm}^{2}\right]$ & $27.8 \pm 5.6$ & $29.5 \pm 4.9$ & $22.6 \pm 3.3$ & $<0.0001$ \\
\hline
\end{tabular}




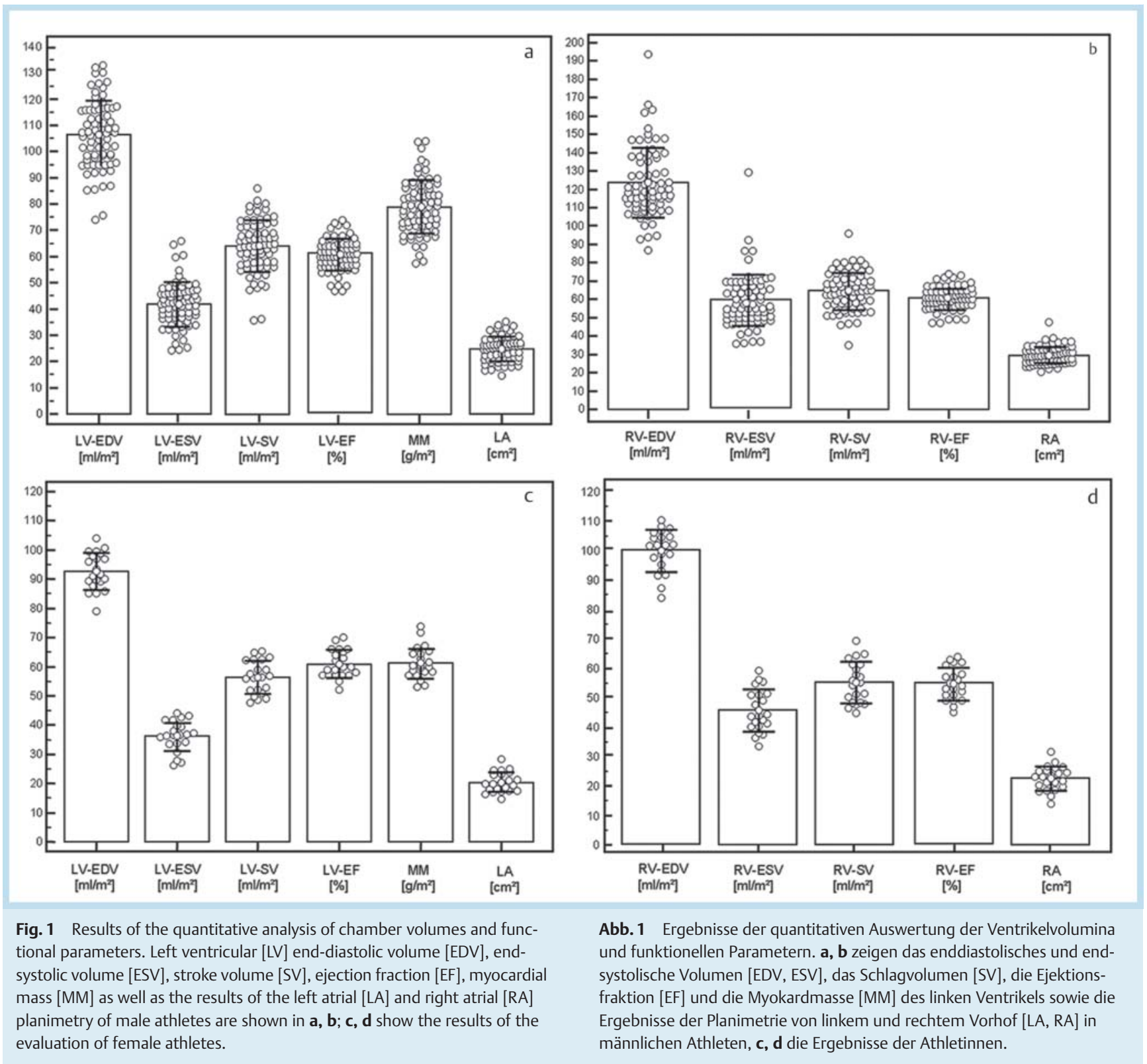

- Fig. 1. The quantitative analyses showed a simultaneous increase of left ventricular chamber size and MM, called eccentric hypertrophy of the left ventricle (LV-EDV: male $106.5 \pm 12.9 \mathrm{ml} /$ $\mathrm{m}^{2}$, female $92.7 \pm 6.4 \mathrm{ml} / \mathrm{m}^{2}$; MM: male $78.9 \pm 10.2 \mathrm{~g} / \mathrm{m}^{2}$, female $61.4 \pm 5.4 \mathrm{~g} / \mathrm{m}^{2}$; remodeling index: male 0.75 , female 0.665 ). Furthermore, an enlargement of the right chamber volumes (RVEDV: male $122.6 \pm 19.0 \mathrm{ml} / \mathrm{m}^{2}$, female $99.9 \pm 7.2 \mathrm{ml} / \mathrm{m}^{2}$ ) and an increased LV-SV (male: $64.7 \pm 10.0 \mathrm{ml} / \mathrm{m}^{2}$, female $56.5 \pm 5.7 \mathrm{ml} / \mathrm{m}^{2}$ ) as well as RV-SV (male: $66.7 \pm 10.4 \mathrm{ml} / \mathrm{m}^{2}$, female $54.2 \pm 7.1 \mathrm{ml} / \mathrm{m}^{2}$ ) were found. The evaluation of the chamber and stroke volumes as well as the MM revealed significantly elevated values for male athletes in comparison to the female study population ( $\bullet$ Table 2 ). The Cohen's kappa test showed good results regarding the interobserver variability ( $\mathrm{k}$-values are also shown in $\bullet$ Table 2 ). There was a significant correlation between weekly training volume and LV$\operatorname{EDV}\left(\mathrm{r}^{2}=0.2375, \mathrm{p}=0.0430\right)$ and LV-ESV $\left(\mathrm{r}^{2}=0.2465, \mathrm{p}=0.0355\right)$ in male athletes whereas in female athletes no significant correlations between chamber volumes and training load were found.
However, pathological findings were detected in 6 athletes (6.3\%).

Regarding the coronary anomalies, we found one case with the circumflex artery originating from the right coronary sinus and course posterior to the ascending aorta ( $\bullet$ Fig. 2 ). Furthermore, one athlete showed an atypical, anterior origin of the right coronary artery (RCA), formally not according to a coronary anomaly but which might cause symptoms of ischemia during exercise due to the long-distance course between the ascending aorta and pulmonary trunk ( $\bullet$ Fig. 3 ). In addition, one athlete was suffering from ectasia of the ascending aorta ( $\bullet$ Fig. 4 ) but had normal blood pressure values $(120 / 80 \mathrm{mmHg}$ ) and in 2 athletes we found pathological signal alterations in the delayed enhancement imaging without corresponding wall motion abnormalities, due to the spot-shaped pattern consistent with a non-ischemic, postinflammatory genesis ( $\bullet$ Fig. 5). In addition, one of the athletes showed pleural effusions and pericardial effusion, but no wall motion abnormalities or delayed enhancement of the myocardium ( $\bullet$ Fig.6). On presentation, the athlete previously experienced a 


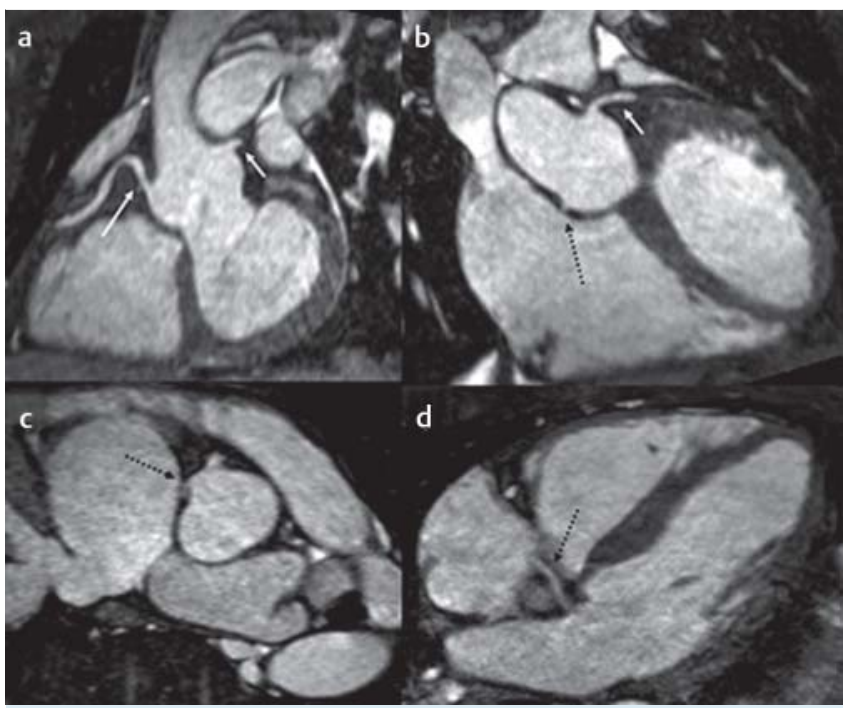

Fig. 2 ECG-gated 3-D MR angiography of a 46-year-old male triathlete with a training load of 18 hours per week. a Origin of the left anterior descending artery from the left sinus (short arrow) and of the right coronary artery from the right sinus (long arrow). $\mathbf{b}+\mathbf{c}$ show the left circumflex artery (LCX), also originating from the right sinus (dotted arrow) and taking course dorsal to the ascending aorta (dotted arrow in $\mathbf{d}$ ), which represents the most common but benign variant of coronary anomaly.

Abb. 2 EKG-getriggerte 3-D-MR-Angiografie eines 46-Jahre alten, männlichen Triathleten mit einem Trainingspensum von 18 Stunden pro Woche. a Abgang des Ramus interventricularis anterior aus dem links-koronaren Sinus (kurzer Pfeil) und der rechten Koronararterie aus dem rechts-koronaren Sinus (langer Pfeil). b+c zeigen den Ramus circumflexus, welcher ebenso dem rechts-koronaren Sinus entspringt (gepunkteter Pfeil) und dorsal der aszendierenden Aorta (gepunkteter Pfeil in d) verläuft, was der häufigsten und als benigne einzustufenden Variante einer Koronaranomalie entspricht.

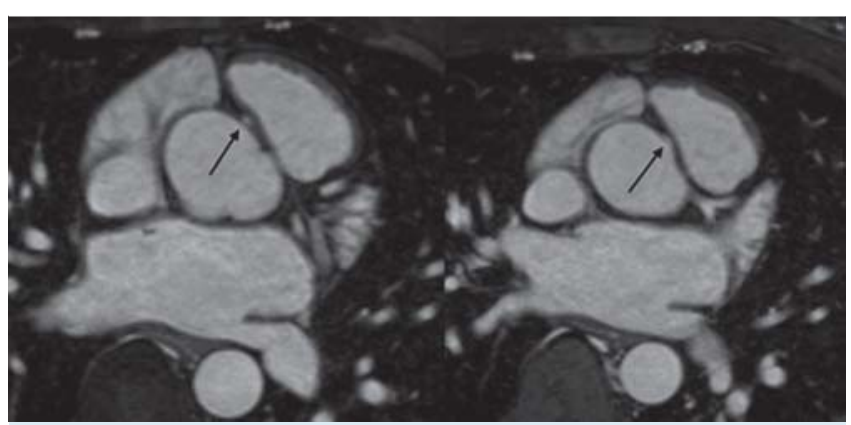

Fig. 3 ECG-gated 3-D MR angiography of a 39-year-old male marathon runner with a training load of 10 hours per week reveals a right coronary artery [RCA] originating from the left corner of the right sinus which is formally not considered as a coronary anomaly but might cause recurrent ischemic alterations due to the long course of the RCA between the aorta and pulmonary trunk.

Abb. 3 EKG-getriggerte 3-D-MR-Angiografie eines 39 Jahre alten, männlichen Marathonläufers mit einem Trainingspensum von 10 Stunden pro Woche. Hier entspringt die rechte Koronararterie [RCA] weit links im Bereich des rechts-koronaren Sinus, was formal nicht als Koronaranomalie erachtet wird, aufgrund des langstreckigen Verlaufs der RCA zwischen Aorta und Truncus pulmonalis jedoch zu rezidivierenden ischämischen Ereignissen führen kann.

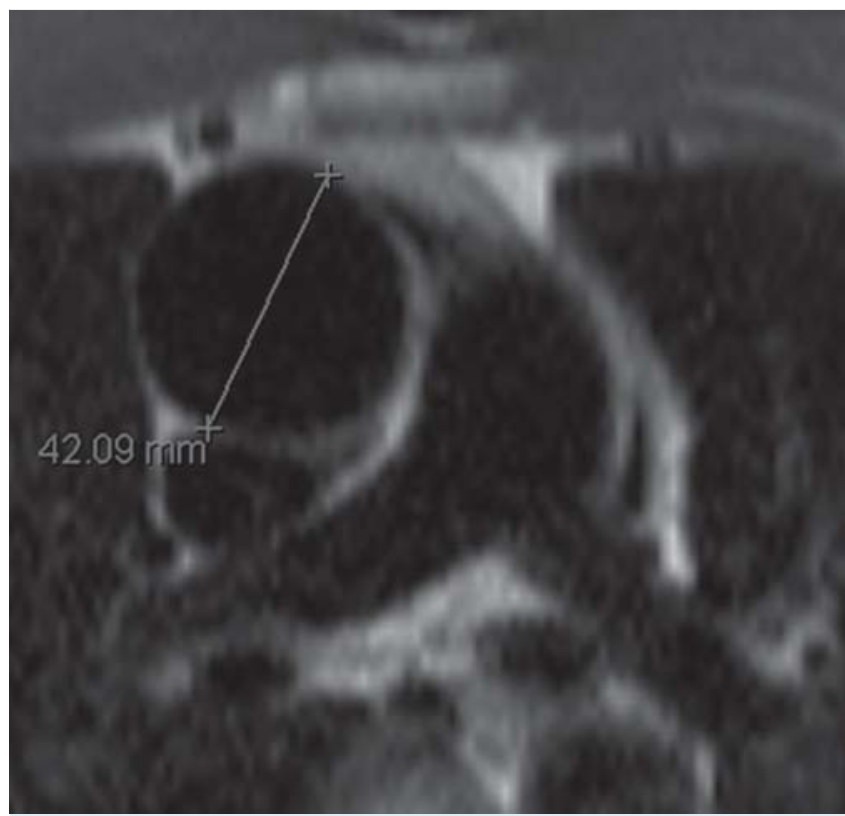

Fig. 4 43-year-old marathon runner with a training load of 10 hours per week. HASTE sequenz shows an ectasia of the ascending aorta of $4.2 \mathrm{~cm}$. This athlete will be closely monitored.

Abb. 4 Die HASTE-Sequenz eines 43-jährigen Marathonläufers mit einem Trainingspensum von 10 Stunden pro Woche zeigte eine Ektasie der Aorta aszendens auf $4,2 \mathrm{~cm}$. Dieser Befund wird engmaschig verlaufskontrolliert.

feverish infection, which turned out to be an Epstein-Barr virus infection. 6 weeks later the athlete underwent a control MRI examination which showed complete recovery.

\section{Discussion}

In the last decades tragic reports of SCD in highly trained athletes have received more and more attention. In most of the cases, cardiovascular diseases such as HCM, myocarditis, ARVD, coronary anomalies and even coronary artery disease are either retrospectively identified or have been ignored by doctors or the athletes $[1,2]$. This has evoked increasing interest in the determination of such acquired or congenital cardiovascular diseases in athletes. In this context, the role of CMR examinations in the screening process is increasingly discussed, especially since routine testing, even in combination with echocardiography may fail in the detection of cardiovascular diseases such as coronary anomalies and subtle myocardial fibrosis that can be found in approximately $30 \%$ of patients with DCM [23]. This is of major importance as the differentiation between "athlete's heart" - characterized by cavity dilatation and eccentric myocardial hypertrophy - and DCM or mild forms of HCM can be difficult. In fact, MRI and especially delayed enhancement imaging may be particularly helpful in making that distinction.

As expected, ventricular volumes and functional parameters as assessed in our cohort are increased for the left and right ventricular EDV, ESV and SV as well as MM in highly-trained athletes as opposed to a non-athlete population [6-8, 24-26]. The remodeling indexes were within normal ranges [8], which is consistent with eccentric hypertrophy. Of note, the remodeling index is reduced in cases of isolated cavity dilatation and increased in 


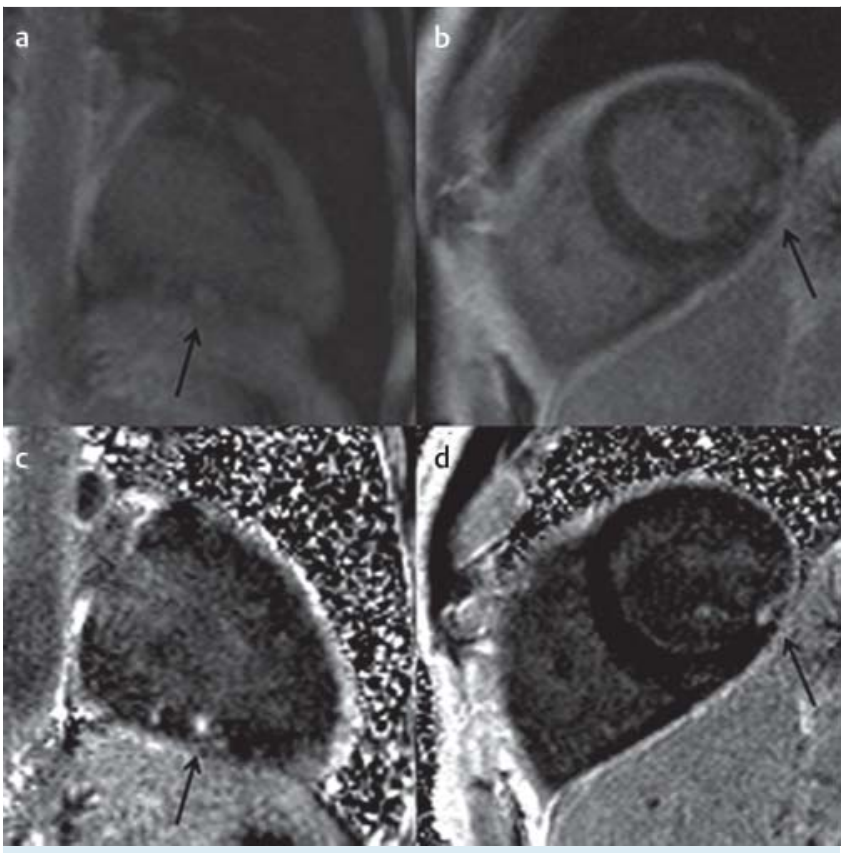

Fig. 5 Delayed enhancement imaging 10 minutes after application of contrast medium of a 47-year-old female cyclist (a, b) and a 50-year-old male cyclist (c, d), both with a training load of 15 hours per week. We found disseminated and intramural myocardial hyperenhancement representative for a non-ischemic type pattern and therefore indicative of a previous myocarditis, in both cases without any wall motion abnormalities.

Abb.5 Delayed-Enhancement-Bildgebung 10 Minuten nach der Injektion von Kontrastmittel, in a, b von einer 47-jährigen Radfahrerin und in c, d von einem 50 Jahre alten, männlichen Radfahrer, jeweils mit einem Trainingspensum von 15 Stunden pro Woche. Hier fanden sich in beiden Athleten disseminierte, intramyokardiale Signalalterationen vom nicht-ischämischen Verteilungsmuster als Zeichen einer stattgehabten Myokarditis, in beiden Fällen ohne Nachweis von entsprechenden regionalen Wandbewegungsstörungen.

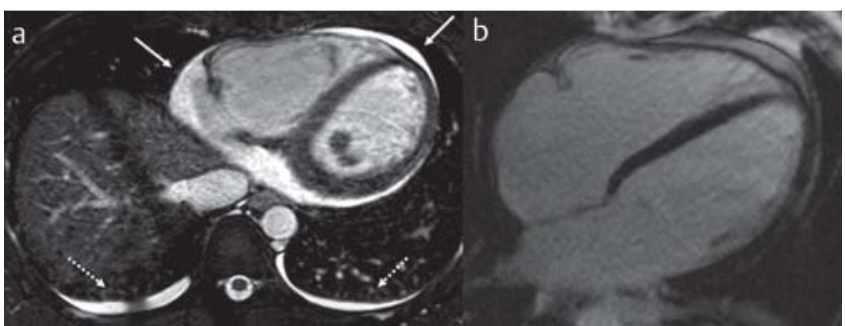

Fig. 6 a ECG-gated 3-D MR angiography of a 29-year-old triathlete reveals pericardial effusion (arrows) and pleural effusions (dotted arrows), but no wall motion abnormalities or $\mathbf{b}$ delayed enhancement of the myocardium. On presentation, the athlete previously experienced a feverish infection, which turned out to be an Epstein-Barr virus infection. 6 weeks later the athlete underwent a control MRI examination which showed complete recovery.

Abb. 6 a EKG-getriggerte 3-D-MR-Angiografie eines 29-jährigen Triathleten mit Nachweis eines Perikardergusses (Pfeile) sowie von Pleuraergüsse (gepunktete Pfeile). Regionale Wandbewegungsstörungen oder $\mathbf{b}$ pathologische Signalalterationen in der delayed enhancement-Bildgebung fanden sich nicht. Anamnestisch gab dieser Athlet einen kürzlich durchgemachten, grippalen Infekt an, welcher sich als Epstein-Barr-Virus Infektion erwies. Eine im Abstand von 6 Wochen durchgeführte Verlaufskontrolle zeigte eine vollständige Rückläufigkeit der vorbeschriebenen Befunde. cases of concentric LV hypertrophy, which is pathognomonic for HCM [19]. Furthermore, the thickness of the interventricular septum was within normal range and there was no asymmetric thickening of the myocardial wall or typical delayed enhancement pattern indicative of HCM [27]. This suggests that the enlargement of the ventricles and the eccentric hypertrophy is a function of physiological changes caused by endurance training. In this context, Petersen et al. [10] showed that physiological LV hypertrophy in athletes can reliably be distinguished from pathological LV hypertrophy such as in HCM. However, the diagnosis of mild forms of HCM is still challenging. Therefore, athletes with a positive family history of HCM, which often shows an autosomal dominant inheritance, should be closely monitored.

The second most common cardiovascular cause of SCD in highly trained athletes is a coronary anomaly [18]. In our study we were able to identify one athlete suffering from the most frequent [28] but benign variant of coronary anomaly, notably a circumflex artery originating from the right sinus ( $\boldsymbol{\Theta}$ Fig. 2). Another athlete showed an RCA originating from the left corner of the right sinus which is formally not considered as a coronary anomaly but might be affected during exercise due to the long course of the RCA between the aorta and pulmonary trunk ( $\bullet$ Fig. 3). However, both athletes had no signs of myocardial ischemia during exercise testing. Also a perfusion defect of the myocardium in an additionally performed adenosine-induced stress perfusion MRI was ruled out in the athlete with the abnormal course of the circumflex artery.

Myocarditis is known to be another common etiology for SCD in young athletes. We found disseminated and intramural myocardial hyperenhancement in two cases. While both athletes denied having a history of cardiovascular disease, this pattern is characteristic of a non-ischemic type and indicates remote myocarditis [19] (० Fig. 5).

As the typical patterns of hyperenhancement in acute myocarditis may decrease during healing and can be almost invisible after recovery [19], false-negative examinations cannot be excluded. With this problem in mind, we identified a restrained, non-ischemic enhancement in a further three athletes ( $\boldsymbol{0}$ Fig. 7). However, as these observations could not be confirmed in a second plane and none of these athletes showed wall motion abnormalities, the findings were judged to be non-significant. The followup MRI examinations performed in the athlete with Epstein-Barr infection revealed complete recovery of the pericardial effusion and no ventricular function impairment.

\section{Prognostic significance of abnormal MRI findings in athletes}

Although the presence of delayed enhancement has prognostic significance in the context of cardiomyopathy [29] and viral myocarditis [30], it remains unclear whether the concept may be transferred to asymptomatic athletes with delayed enhancement of non-ischemic origin. More than two years after the MRI, both athletes are still performing their activity (mountain biking) without any symptoms. Holter-ECG was performed in one of these athletes twice (the other athlete refused additional testing) and no relevant heart rhythm disorders could be detected.

The relevance of coronary anomalies in asymptomatic persons is still under debate. Coronary anomalies are disproportionately common in young athletes suffering from SCD. However, the athlete in our study was 46-years-old and had been performing high-intensity training for several years. Whether this athlete has a higher risk for SCD even in the absence of symptoms like 


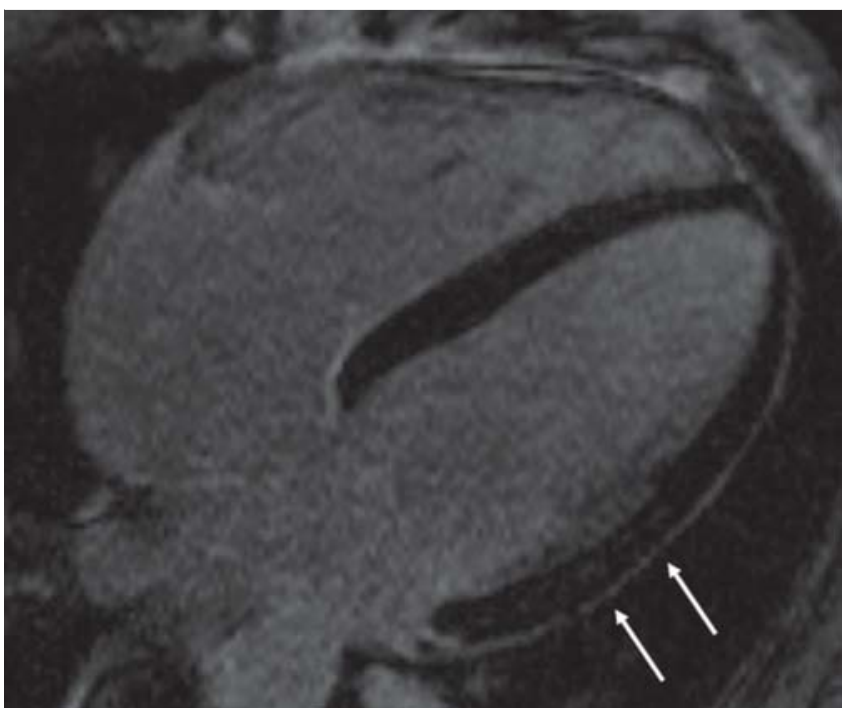

Fig. 7 Delayed enhancement imaging of a 36-year-old runner with a training load of 20 hours per week shows disseminated and intramural myocardial hyperenhancement of the lateral wall (arrows). These findings could not be confirmed in a second plane and were therefore judged to be non-significant.

Abb.7 In der Delayed-Enhancement-Bildgebung eines 36-jährigen Läufers mit einem Trainingspensum von 20 Stunden pro Woche fanden sich disseminierte, intramyokardiale Signalalterationen im Bereich der lateralen Wandsegmente (Pfeile), welche sich jedoch nicht zuverlässig in einer 2. Ebene bestätigen ließen und somit als nicht-signifikant eingestuft wurden.

fainting or proven myocardial ischemia remains to be seen. Ultimately, none of the above-mentioned athletes was restricted from sports competition.

\section{Study Limitations}

Certainly, this study has some major limitations. A control collective consistent of non-athletes was not examined and the quantitative analyses of the RV were performed using short axis slices. No additional axial slices were acquired. Moreover, a work-up (adenosine-stress MRI, Holter-ECG, repeated MRI) was only performed in the case of pathological findings. Thus, it remains unclear whether athletes with an initially unremarkable MRI would present abnormal findings during further examinations.

\section{Conclusion}

Routine implementation of CMR imaging in the context of preparticipation screening of highly-trained athletes revealed abnormal findings in more than 5 percent of all athletes and is a useful tool in the detection of cardiovascular disease. However, the prognostic significance of these findings remains unclear. Thus, cardiac MRI cannot be recommended as a routine examination in the care of athletes.

\section{Acknowledgements}

The study was funded by the German Heart foundation.

\section{References}

1 Prakken NH, Velthuis BK, Cramer MJ et al. Advances in cardiac imaging: the role of magnetic resonance imaging and computed tomography in identifying athletes at risk. Br J Sports Med 2009; 43: 677-684

2 Corrado D, Basso C, Rizzoli G et al. Does sports activity enhance the risk of sudden death in adolescents and young adults? J Am Coll Cardiol 2003; 42: 1959-1963

3 Maron BJ, Bodison SA, Wesley YE et al. Results of screening a large group of intercollegiate competitive athletes for cardiovascular disease. J Am Coll Cardiol 1987; 10: 1214-1221

4 Maron BJ, Thompson PD, Puffer JC et al. Cardiovascular preparticipation screening of competitive athletes. A statement for health professionals from the sudden death committee (clinical cardiology) and congenital cardiac defects committee (cardiovascular disease in the young), American Heart Association. Circulation 1996; 94: 850-856

5 Corrado D, Basso C, Schiavon $M$ et al. Screening for hypertrophic cardiomyopathy in young athletes. New Engl J Med 1998; 339: 364-369

6 Sandstede J, Lipke C, Beer $M$ et al. Age- and gender-specific differences in left and right ventricular cardiac function and mass determined by cine magnetic resonance imaging. Eur Radiol 2000; 10: 438-442

7 Scharhag J, Schneider G, Urhausen A et al. Athlete's heart: right and left ventricular mass and function in male endurance athletes and untrained individuals determined by magnetic resonance imaging. J Am Coll Cardiol 2002; 40: 1856-1863

8 Scharf $M$, Brem $M H$, Wilhelm $M$ et al. Atrial and ventricular functional and structural adaptations of the heart in elite triathletes assessed with cardiac MR imaging. Radiology 2010; 257: 71 - 79

9 Perseghin G, De Cobelli F, Esposito A et al. Effect of the sporting discipline on the right and left ventricular morphology and function of elite male track runners: a magnetic resonance imaging and phosphorus 31 spectroscopy study. Am Heart J 2007; 154: 937-942

10 Petersen SE, Selvanayagam JB, Francis JM et al. Differentiation of athlete's heart from pathological forms of cardiac hypertrophy by means of geometric indices derived from cardiovascular magnetic resonance. J Cardiovasc Magn Reson 2005; 7: $551-558$

11 Grafe MW, Paul GR, Foster TE. The preparticipation sport examination for high school and college athletes. Clin Sports Med 1997; 16: 570 591

12 Glover DW, Maron BJ. Profile of preparticipation cardiovascular screening for high school athletes. JAMA 1998; 279: 1817-1819

13 Pfister GC, Puffer JC, Maron BJ. Preparticipation cardiovascular screening for US collegiate student-athletes. JAMA 2000; 283: 1597-1599

14 Maron BJ. Hypertrophic cardiomyopathy: a systematic review. JAMA 2002; 287: $1308-1320$

15 Corrado D, Thiene G, Nava A et al. Sudden death in young competitive athletes: clinico-pathologic correlations in 22 cases. Am J Med 1990; 89: $588-596$

16 Thiene G, Nava A, Corrado D et al. Right ventricular cardiomyopathy and sudden death in young people. N Engl J Med 1988; 318: 129-133

17 Sofi F, Capalbo A, Pucci $N$ et al. Cardiovascular evaluation, including resting and exercise electrocardiography, before participation in competitive sports: cross sectional study. BMJ 2008; 337: 88-106

18 Prakken NH, Cramer MJ, Olimulder MA et al. Screening for proximal coronary artery anomalies with 3-dimensional MR coronary angiography. Int J Cardiovasc Imaging 2010; 26: $701-710$

19 Mahrholdt H, Wagner A, Judd RM et al. Delayed enhancement cardiovascular magnetic resonance assessment of non-ischaemic cardiomyopathies. Eur Heart J 2005; 26: 1461 - 1474

20 Achenbach S, Barkhausen J, Beer $M$ et al. Consensus recommendations of the German Radiology Society (DRG), the German Cardiac Society (DGK) and the German Society for Pediatric Cardiology (DGPK) on the use of cardiac imaging with computed tomography and magnetic resonance imaging. Fortschr Röntgenstr 2012; 184: 345-368

21 Hergan K, Globits S, Schuchlenz H et al. Clinical relevance and indications for cardiac magnetic resonance imaging 2013: an interdisciplinary expert statement. Fortschr Röntgenstr 2013; 185: 209-218

22 Luijnenburg SE, Robbers-Visser D, Moelker A et al. Intra-observer and interobserver variability of biventricular function, volumes and mass in patients with congenital heart disease measured by CMR imaging. Int J Cardiovasc Imaging 2010; 26: 57-64

23 McCrohon JA, Moon JC, Prasad SK et al. Differentiation of heart failure related to dilated cardiomyopathy and coronary artery disease using gadolinium-enhanced cardiovascular magnetic resonance. Circulation 2003; 108: 54-59 
24 Tandri H, Daya SK, Nasir K et al. Normal reference values for the adult right ventricle by magnetic resonance imaging. Am J Cardiol 2006; 98 : 1660 - 1664

25 Maceira AM, Prasad SK, Khan M et al. Reference right ventricular systolic and diastolic function normalized to age, gender and body surface area from steady-state free precession cardiovascular magnetic resonance. Eur Heart J 2006; 27: 2879-2888

26 Zandrino F, Molinari G, Smeraldi A et al. Magnetic resonance imaging of athlete's heart: myocardial mass, left ventricular function, and crosssectional area of the coronary arteries. Eur Radiol 2000; 10: 319-325
27 Bischoff P, Radke PW, Barkhausen J et al. The thickened left ventricle: etiology, differential diagnosis and implications for cardiovascular radiology. Fortschr Röntgenstr 2012; 184: 697-705

28 Wilkins CE, Betancourt B, Mathur VS et al. Coronary artery anomalies: a review of more than 10,000 patients from the Clayton Cardiovascular Laboratories. Tex Heart Inst J 1988; 15: 166-173

29 Sanz J. Evolving diagnostic and prognostic imaging of the various cardiomyopathies. Ann N Y Acad Sci 2012; 1254: 123-130

30 Grün S, Schumm J, Greulich S et al. Long-term follow-up of biopsy-proven viral myocarditis: predictors of mortality and incomplete recovery. J Am Coll Cardiol 2012; 59: 1604-1615 